\title{
Maybury-Lewis por Maybury-Lewis
}
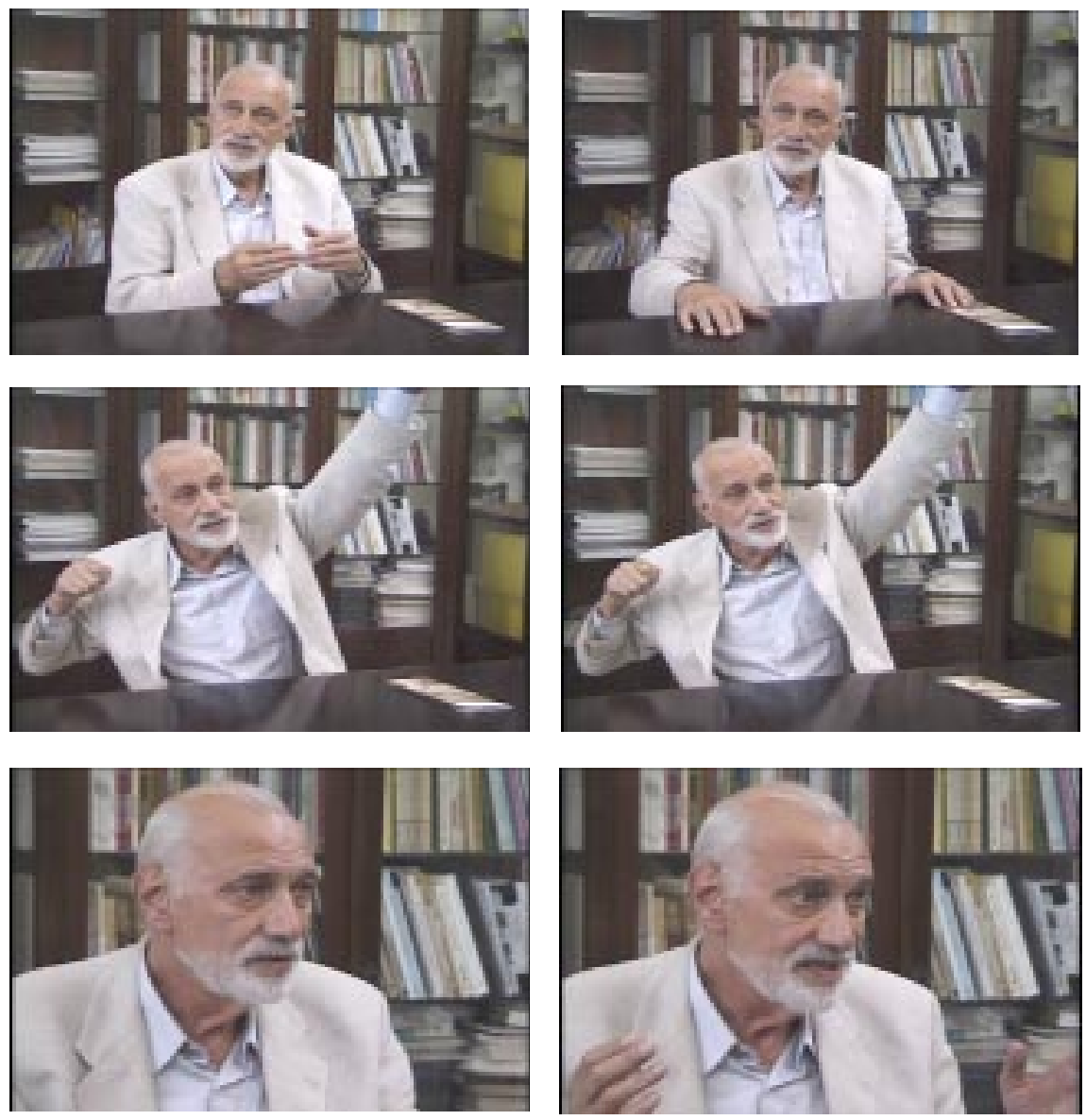

David Maybury-Lewis no LISA (Laboratónio de Imagem e Som em Antropologia), outubro de 2001. 
0 texto a seguir é resultado de dois encontros com 0 autor, ambos ocorridos em 26 de outubro de 2001.0 primeiro se deu por ocasião do evento "Sexta do mês", oferecido pelo D epartamento de Antropologia daUSP, em que MayburyLewis foi convidado para falar de sua trajetória intelectual. $O$ segundo teve lugar no Laboratório de Imagem e Som em Antropologia (LISA/ USP), onde 0 antropólogo foi entrevistado por Sylvia Caiuby Novaes, Renato Sztutman, Edgar Cunha e Chico Paes.

\section{Os selvagens da infância}

Não tenho certeza, pois não sou psiquiatra, mas a impressão que eu tenho é que meus primeiros encontros com a alteridade aconteceram durante a minha infância passada na Índia. Meus pais eram britânicos e, na época, ainda vivíamos em uma colônia britânica. Morávamos em uma região que pertence, hoje em dia, ao Paquistão. Lá eu nasci, fui criado e vivi até os meus sete anos. Partimos, então, à Inglaterra, onde passei a morar em um internato tipicamente britânico. Foi um choque tremendo, do ponto de vista ao mesmo tempo físico e moral, sobretudo para alguém que estava acostumado a passear por aqueles jardins brilhantes que os ingleses mantinham na Índia.

Os selvagens da minha infância foram os cameleiros. Eu era o caçula da família e meu pai era engenheiro, construía barragens e cuidava da grande teia de canais que distribuíam as águas do rio Indus. Ele, como oficial britânico, tinha direito, quando se deslocava, a vinte e quatro camelos e eu adorava brincar com os cameleiros, que eram muito simpáticos comigo. Nossos empregados diziam que eles eram pessoas selvagens e que eu não devia sequer lhes falar. D e todo modo, a comunicação era muito difícil, pois eles não falavam a minha língua, tampouco a dos nossos empregados, o que me levava a crer que eles eram visivelmente diferentes. Mas quanto mais me separavam deles, mais aumentava o meu desejo em brincar com eles. Foi assim o meu primeiro contato com os chamados selvagens, com a alteridade. 
Essa é uma experiência que guardei na memória, uma experiência que passou a fazer parte do meu passado. Nunca mais voltei à Índia, nunca mais tive contato com pessoas como os cameleiros. Foi somente quando comecei a trabalhar como antropólogo e a pensar nas questões da alteridade que pude me lembrar das experiências que tive na infância e nas suas possíveis conexões com a minha formação e com 0 meu desejo de ser Antropólogo.

\section{0 gosto pela diversidade}

Houve um intervalo bastante longo entre os anos de infância na Índia e o meu primeiro contato com a Antropologia, que aconteceu na Universidade de Cambridge. Naquela época, eu me interessava por línguas e havia decidido estudar todas as línguas importantes da Europa. Acabei privilegiando o espanhol, o francês, o alemão e o russo, que passei a falar fluentemente. Ironicamente, as línguas que eu mais uso na minha vida não são essas quatro, mas sim o português e o dinamarquês, língua materna de minha esposa, Pia.

Com tudo isso, eu não tinha a menor idéia do que ia fazer depois de me graduar. Assisti a uma série de aulas sobre o descobrimento das Américas e os indígenas que lá habitavam, assunto pelo qual comecei a me interessar. Em 1952, durante o encontro de americanistas que aconteceu em Cambridge, uma coincidência mudou a minha vida. Fui assistir à apresentação dos trabalhos e conversar com alguns professores para saber se havia qualquer possibilidade, para mim que não falava língua indígena alguma e que não possuía qualificação prévia, de viajar às Américas para estudar os índios.

A maioria dos professores fez exatamente o que eu faria hoje em dia se alguém se dirigisse a mim com 0 mesmo pedido. Diziam não saber quais as minhas verdadeiras chances, no entanto me desejavam boa sorte. 0 único que expressou uma postura diferente foi o professor 
Herbert Baldus, que me encorajou a partir para o Brasil, onde poderia passar a vida inteira fazendo pesquisa e produzindo ciência. Vendo logo que eu era inglês, propôs que, em vez de partir diretamente ao Brasil, cujo governo impunha muitas dificuldades à pesquisa, eu principiasse as minhas investigações na $G$ uiana Inglesa, de onde poderia chegar mais facilmente, apenas atravessando a fronteira, à Amazônia brasileira. Disse também que estava disposto a me orientar e me ajudar a desenvolver os meus conhecimentos em Etnologia. Saí da sala e pensei que encontrara ali uma pessoa com a qual eu gostaria de estudar. Acabara de me convidar para atravessar uma fronteira que eu mal sabia onde se localizava e para encontrar tribos desconhecidas. Era esse o orientador que eu esperava.

\section{Em São Paulo}

Então foi o que foi. Não exatamente do modo que Baldus propôs, mas de maneira mais prosaica. Eu e Pia nos mudamos para São Paulo e logo consegui um emprego na Cultura Inglesa. Baldus teve uma grande surpresa: aquele rapaz com quem havia conversado por não muito mais que cinco minutos estava ali em seu escritório, disposto a aprender etnografia. Foi na Escola Livre de Sociologia e Política, junto a Baldus, que descobri a etnografia brasileira. Lá tive a oportunidade de estudar com professores conhecidos como O racy Nogueira, Juarez Brandão Lopes, Otávio da Costa Eduardo, Donald Pierson e outros mais. Sempre tive muita admiração pelo estilo de Baldus, um homem que ia até as margens da civilização e só voltava quando o dinheiro acabava.

Uma pessoa com a qual fui ter contato apenas anos depois foi Florestan Fernandes. Na época de minha chegada a São Paulo, eu não sabia o que era a USP e tampouco quem eram os seus professores. Morava em um apartamento pequeno e, quando muito, ia de lá até a Cultura Inglesa e a Escola Livre de Sociologia e Política. Q uando tomei 
conhecimento desse outro ambiente, momento também em que passei a entender realmente os padrões da Etnologia brasileira, fui procurar 0 professor Florestan, que me dizia estar muito magoado por eu ter demorado tanto a procurá-lo. D esculpei-me, mas, àquela altura, já havia sido Baldus o meu grande formador.

\section{Curt Nimuendaju}

Baldus me incentivou a fazer pesquisa com povos bastante remotos do Brasil Central, realmente o que eu queria. Ele apresentou-me, então, aos trabalhos de Curt Nimuendaju. Logo percebi que havia ali dados riquíssimos, mas também algo problemáticos, sobretudo no que dizia respeito aos povos timbira e xerente. Nimuendaju era um romântico. Para ele, as sociedades que estudava estavam de certo modo deformadas pelo contato com os brancos. Ele escreveu um livro enorme sobre os Timbira Orientais, com dados riquíssimos, mas sempre com aquela queixa constante de que o sistema estava mudando dada a influência do mundo dos brancos, estava se deturpando, se afastando cada vez mais do que devia ser antigamente. Tratava-se, para Nimuendaju, sempre da busca de uma organização social anterior, mas eu me perguntava se era realmente possível essa reconstrução. O s seus livros continham frases que apontavam um estado de aculturação, um colapso no funcionamento dos sistemas tradicionais. Assim, Nimuendaju idealizava um passado quando defrontado com os dados que obtinha do presente.

\section{Notícias dos Xavante, viagem aos Xerente}

Tendo em vista os dilemas de Nimuendaju, Baldus sugeriu que eu procurasse um grupo indígena que houvesse passado pelo menor contato possível com os brancos. Os Xavante eram esse grupo por permanecerem praticamente alheios à nossa sociedade. Conhecia-os 


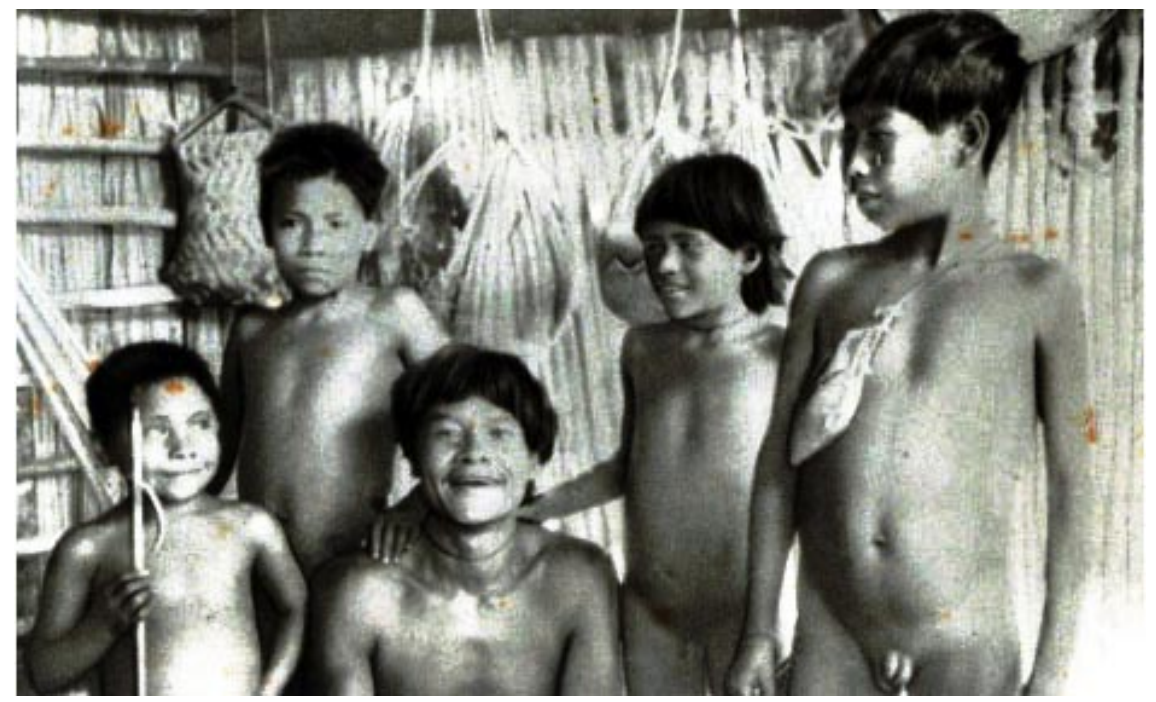

Os Xerente, com os quais David passou oito meses (extraído de The savage and the innocent, 1965)

apenas por certas fotografias tiradas de aviões que sobrevoavam as suas aldeias, nas quais era possível vê-los saindo de suas malocas atirando para cima com seus arcos e flechas. Eles tinham fama de selvagens, bravos, hostis. Baldus, em 1951, escreveu um artigo, se não me engano publicado no jornal $\mathrm{O}$ Estado de S. Paulo, intitulado "É belicoso 0 X avante?”. Evidentemente, quem conheceu Baldus sabe de antemão a sua resposta: não, eles não são belicosos, estão apenas se defendendo e somos nós que estamos invadindo as suas terras.

Mesmo diante de tantas dificuldades, eu e Pia estávamos convencidos de nossa idéia de levar adiante a pesquisa entre os Xavante. Acreditávamos, como Baldus, que eles não eram naturalmente belicosos - mas como fazer para que eles soubessem dessa nossa posição, para que eles nos aceitassem como amigos e nos distinguissem dos inimigos regionais que abundavam na época (e continuam abundantes até hoje)? Sabíamos também que seria difícil para nós estabelecer contato com 
eles, uma vez que era extremamente improvável que compreendessem o português. Foi então que traçamos nosso plano de pesquisa: viveríamos um tempo entre os Xerente, grupo que contava com maior experiência de contato, para depois encontrar os Xavante, dada a proximidade lingüística e geográfica verificada entre ambos os grupos. Partimos, então, aos X erente e passamos cerca de um ano por lá fazendo pesquisa de campo e sofrendo para aprender a língua deles.

Q uando voltamos do campo, redigi e defendi minha tese de mestrado na Escola Livre de Sociologia e Política. D epois disso, retornamos para Inglaterra e ingressei na Universidade de Oxford, onde morava a minha família. Permanecemos na casa de meus pais, pois não recebia bolsa de estudos. Em 1956, submeti-me a exames, e, assim que obtive o diploma deAntropologia Social, fui aceito como doutorando na Universidade de Oxford. Passei a ser orientado pelo Professor Rodney Needham, não porque ele possuísse muitos conhecimentos sobre os índios brasileiros, mas sobretudo porque abrigava os alunos que não estudavam a África. Foi assim que, em 1957, parti, com Pia e nosso filho de apenas um ano, para os Xavante. Quando falamos da nossa decisão de levar conosco 0 nosso filho, a reação de nossos pais, os meus e de Pia, foi aquela que se pode esperar. Acusaram-nos de irresponsáveis e pediram para que deixássemos o menino com eles. Por um momento, propus a Pia que permanecesse em $\mathrm{Oxford}$, mas ela relutou, disse que também fazia parte da pesquisa, e insistiu na ida do menino. "Os Xavante não têm filhos? Se têm, por que eu não posso levar o meu para lá?”, rebateu ela. E fomos para lá com o menino, que, se não me engano, aprendeu a andar e a falar entre os Xavante.

\section{A chegada}

Nunca esquecerei o momento de nossa chegada. 0 avião da FAB sobrevoava a aldeia Pimentel Barbosa e víamos pela primeira vez aquilo 
tudo ao vivo, exatamente como havíamos imaginado. Os Xavante saíam correndo de suas malocas, tais quais atletas das primeiras olimpíadas na $\mathrm{G}$ récia, e corriam para 0 campo de pouso. $\mathrm{O}$ avião pousou e

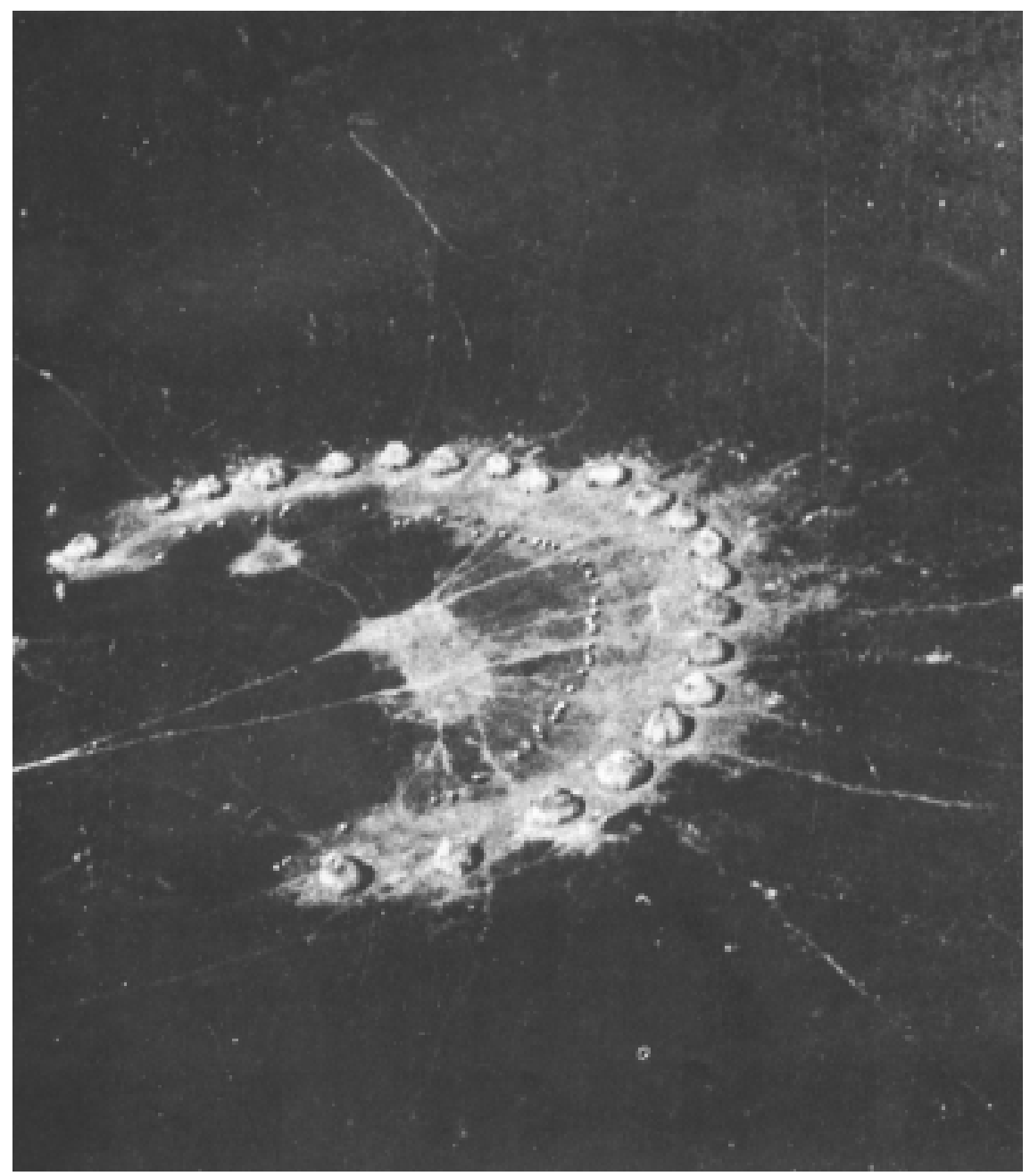

Vista aérea de uma aldeia xavante antes da pacificação. 
o piloto-capitão se pôs a jogar todas as nossas coisas e mantimentos no chão. Em nosso apartamento no Largo do Arouche, em São Paulo, pensávamos que havia mantimentos o bastante para a estadia de um ano entre os Xavante, mas ao vermos tudo ao chão, percebemos que as coisas não seriam bem assim. Minutos depois, o mesmo capitão nos avisou que teria de partir de imediato pois evitava o encontro com os índios. Víamo-nos, subitamente, sozinhos e sem jeito no meio do Brasil Central. Logo chegaram os X avante que notaram prontamente a tipóia, feita pelos Xerente, para criança de colo que Pia carregava. Em meu xerente desajeitado, pedi para que eles nos ajudassem a levar as coisas para a aldeia. Eles morreram de rir, afinal foi uma grande surpresa ouvir de nós algo compreensível, mesmo que falado de modo esquisito ou mesmo ridículo. D e todo modo, levaram todos os nossos pertences para a aldeia e, ao contrário de nossos temores, tivemos uma entrada triunfal.

\section{A vida na aldeia}

Imediatamente, Pia se deu bem com eles, participava daquelas andanças longas com as mulheres para colher frutas e raízes. 0 menino brincava totalmente à vontade com as crianças da aldeia. $\mathrm{A}$ única pessoa que não possuía um papel definido era eu, que não sabia fazer as coisas mais

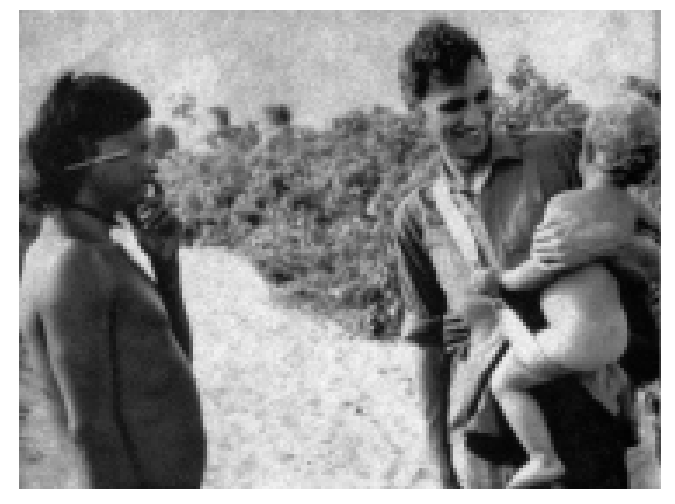

David com seu filho e um refugiado de Marawasede (extraído de The savage and the innocent, 1965) 
MaybURY-LeWis Por MaybURY-LeWIS

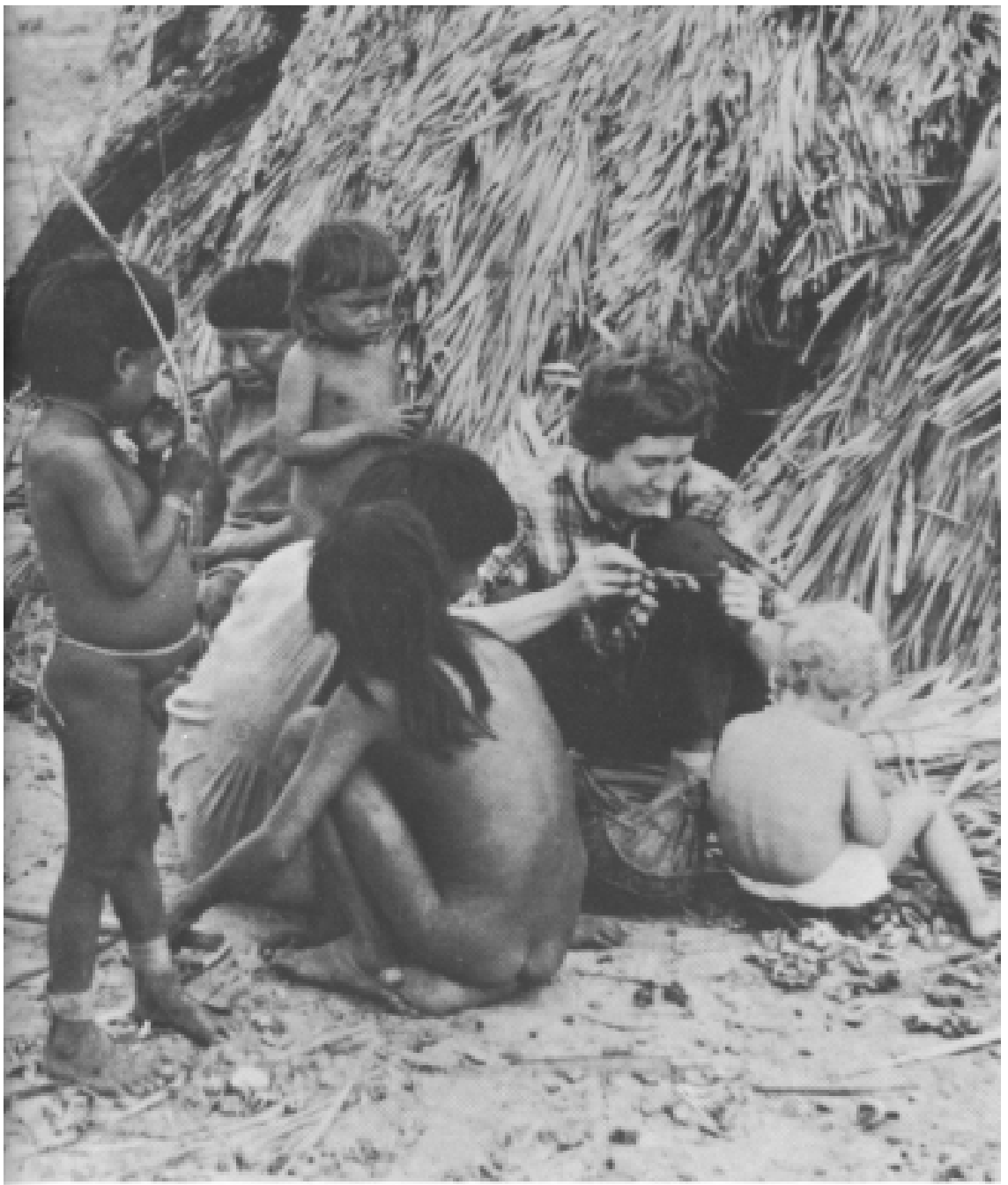

Pia e Biom em casa com os Xavante (extraído de The savage and the innocent, 1965) 
elementares que os homens deviam fazer. Por exemplo, quando um Xavante sai para caçar, jamais sai sozinho; ele, no entanto, não chama todos os seus colegas, sai simplesmente e, dez minutos depois, é seguido por companheiros. Mas eu era incapaz de fazer isso, e eles descobriam que eu era ali como uma criança, me perdia com facilidade, trazia coisas idiotas, fazia perguntas imbecis. Eles começaram a me tratar, então, como um sobrinho, como um bobo. À noite, me convidavam para sentar no círculo dos homens maduros no centro da aldeia $\mathrm{e}$ logo começavam a rir, caindo no chão de tanto gargalhar - e eu bem sabia que 0 alvo era eu. Percebi que eu havia adquirido, entre os Xavante, o papel de uma espécie de programa cômico de televisão.

E u raramente dormi na casa dos wapté [solteiros]. Só o fazia quando os acompanhava em andanças. Pouco depois de nossa chegada, dormíamos em uma casa que construíram para nós no círculo da aldeia. Era uma casinha ao lado da casa do chefe, que me tratou como um filho. E eu tinha de chamar os outros filhos dele de irmãos, e os solteiros me chamavam de cunhado. 0 único incidente que ocorreu por ali foi quando resolveram fazer uma reforma na casa do chefe e, de repente, estava lá toda a sua família em nossa casa, e mais ou menos dezesseis ou dezessete pessoas tiveram de dormir juntas.

Os X avante saíam em andanças o tempo todo para caçar. Às vezes, eu acompanhava esses grupos e Pia ficava na aldeia, com 0 menino. Q uando eu estava na casa dos solteiros, o difícil era compartilhar a comida que levava e que não era suficiente para todos. Mas eu sempre compartilhava com alguém, o que faz parte da tradição xavante. Chamava um amigo, um jovem xavante, para dividir o prato. Cada dia, o mesmo havia de se dar com uma pessoa diferente. $O$ que eu tinha, sobretudo no café da manhã, era farinha misturada com leite em pó e com um pouco de açúcar. 
Maybury-Lewis por Maybury-LewiS

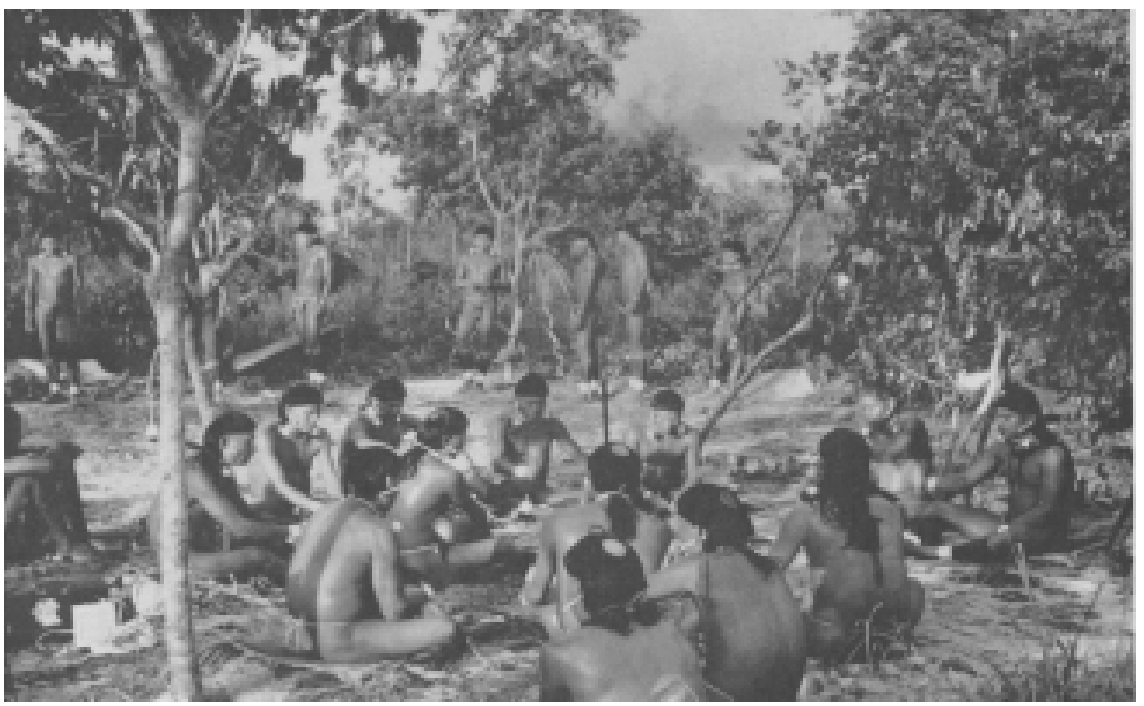

Wai 'á, ritual masculino xavante (foto de Maybury-Lewis extraída de Akwe-Xavante society, 1967)

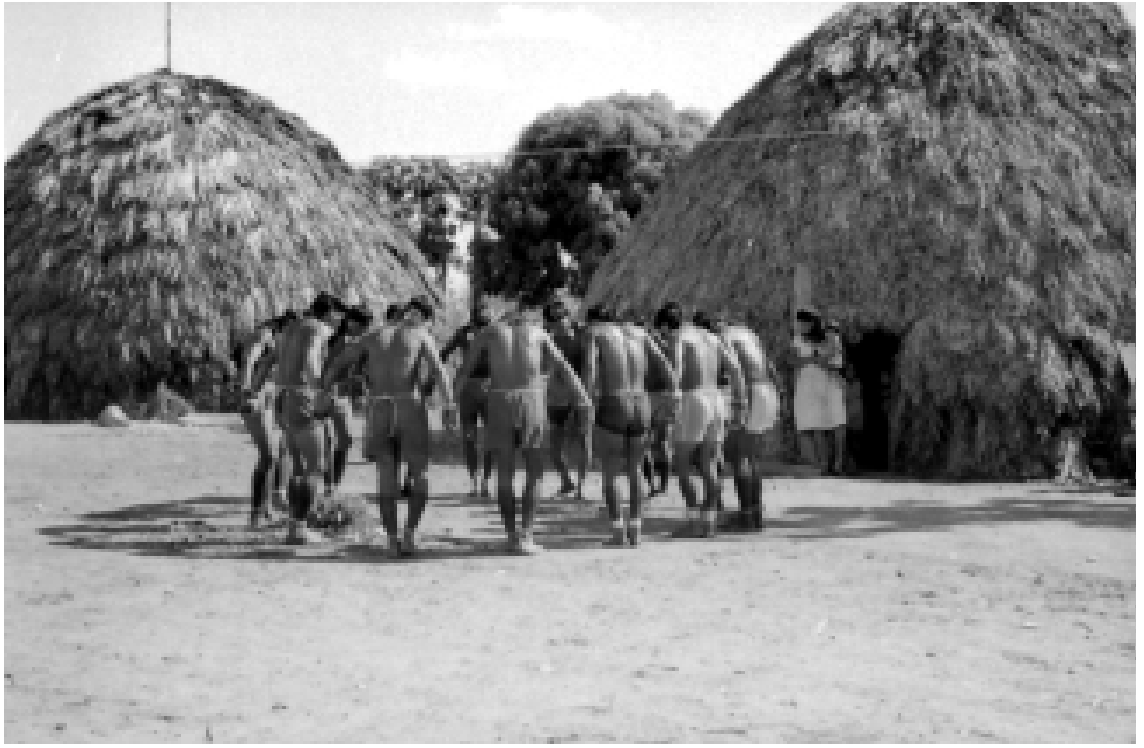

Wai á, nitual masculino xavante (foto de Sylvia Caiuby N ovaes, 1972) 
Revista de Antropologia, São Paulo, USP, 2002, v. 45 no 12

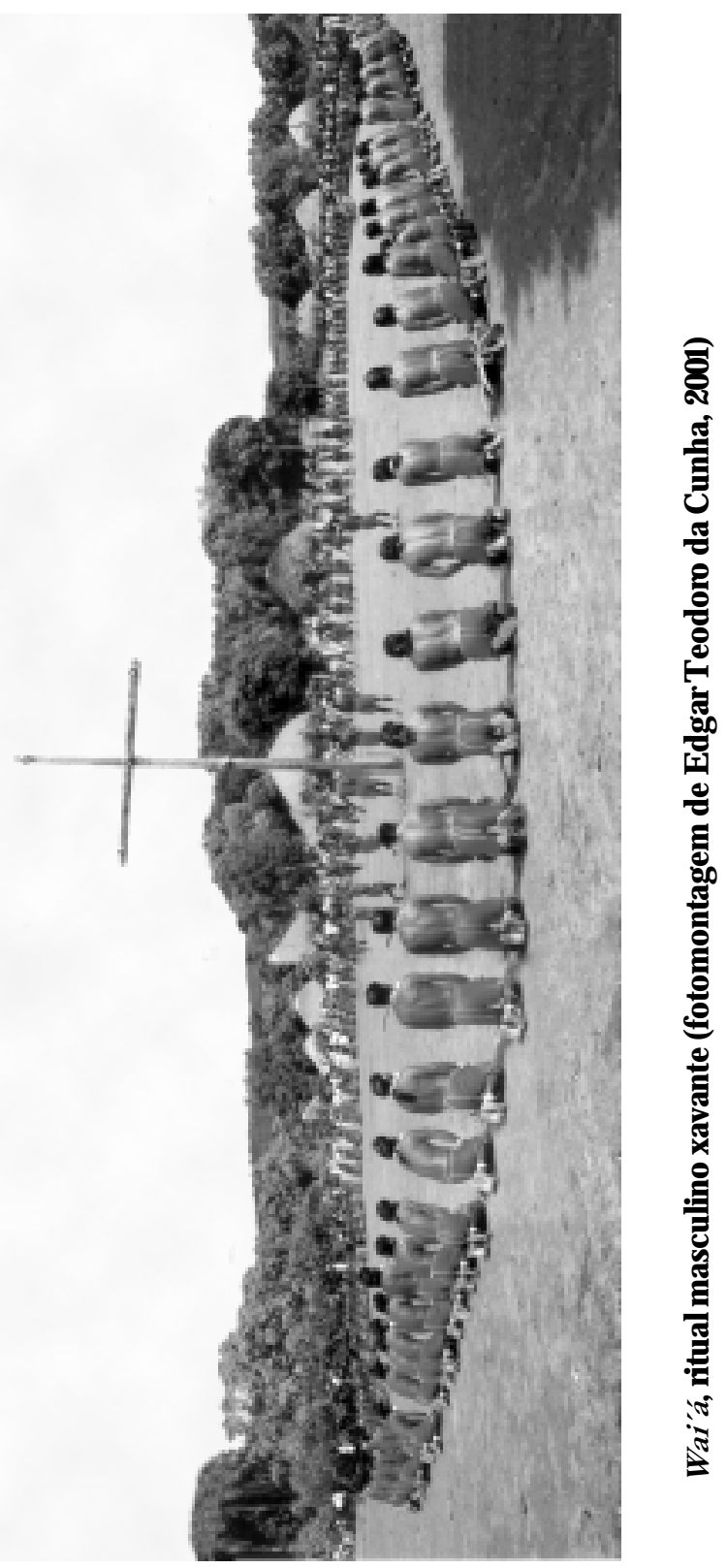




\section{De volta à academia}

D epois de realizada a pesquisa entre os Xavante, retornei mais uma vez à minha terra, a Inglaterra, para redigir a minha tese. Na defesa de meu doutoramento, tive o prazer e a honra de ser examinado por dois antropólogos célebres. Era necessário um professor de Oxford e um professor de fora. $\mathrm{O}$ primeiro foi Evans-Pritchard, o segundo, Edmund Leach. É de se imaginar o meu medo quando cheguei à sala de defesa e vi que Leach havia preenchido o quadro com símbolos de parentesco, tudo aquilo extraído de minha tese. Naquele momento, eu, completamente sem jeito, mal me lembrava do que se tratava, não queria falar. Começada a defesa, Leach perguntou se havia homossexualidade entre os X avante. Eu, inocentemente, disse não ter percebido algo parecido, pois não era esse 0 tema de minha pesquisa. Nas noites que passei na casa dos solteiros, nada havia notado, o que não me permitia lançar afirmações. De repente, ambos levaram adiante a discussão, argumentando um contra o outro, como se eu não estivesse lá. No início do exame eu não me importava em ser marginalizado dessa maneira, mas depois de um tempo, comecei a sentir uma certa frustração. Afinal de contas, quem era 0 examinado? Não seria ele quem deveria ter o papel principal no rito? A resposta não demorou. Os dois examinadores famosos voltaram sua plena atenção para mim e depois de mais uma meia hora eu fiquei feliz de poder sair de lá ileso, e com o título de doutor.

Pouco depois, fui convidado para ocupar o cargo de instrutor na Universidade de Harvard. Instrutor era o menor grau de toda a hierarquia americana do departamento de Antropologia. Em 1960, parti para Harvard, pensando em permanecer ali por cerca de dois anos. Mas acabei por encontrar nos Estados Unidos boas condições de pesquisa e, sobretudo, financiamento para minhas pesquisas no Brasil Central, 0 que me fez adiar minha volta para a Inglaterra até que descobrimos que estávamos radicados nos Estados Unidos. 


\section{Claude Lévi-Strauss}

Tive conhecimento da obra de Lévi-Strauss antes de fazer a pesquisa, em Oxford. As sociedades do Brasil Central foram mencionadas em As estruturas elementares do parentesco, de 1949, e analisadas em artigos publicados ao longo dos anos 1950. Tomei conhecimento dessa literatura por meio de Rodney Needham, um grande especialista em estruturalismo. Eu sempre duvidei das análises de Lévi-Strauss por não corresponderem às coisas que eu acreditava ter encontrado entre os Xerente e Xavante. Meu problema era 0 de reconciliar as análises estruturalistas de Lévi-Strauss com aquelas que eu vinha desenvolvendo no Brasil Central. Essa foi uma preocupação constante durante a elaboração dos meus dados. Tirei uma licença da Universidade de Harvard, voltei para a Universidade de Cambridge, onde permaneci um ano escrevendo. Lá comecei a redigir um comentário extenso a As estruturas elementares..., que consistia em uma crítica à aplicação dessas idéias às sociedades do Brasil Central. Infelizmente. Eu nunca publiquei esse trabalho, pois um dia reli tudo aquilo e percebi que se tratava de uma crítica severa demais. D evemos reconhecer a contribuição de Lévi-Strauss e, ao mesmo tempo, saber criticar e entender quais são os pontos de divergência. Não publiquei a crítica, mas continuei a trabalhar com essa divergência entre as coordenadas estruturais e as minhas análises.

\section{0 projeto Harvard Brasil Central}

$\mathrm{Eu}$ sempre tive vontade de fazer um estudo comparativo no Brasil Central quando pensava nos dados de que dispunha naquela época. Parti então para uma antropologia comparada naquela região, a começar pela consideração das obras de Nimuendaju, passando pelas minhas próprias e continuando com as dos meus alunos. O projeto comparativo foi inventado em Harvard e depois discutido com Roberto Cardoso de O liveira, do Museu Nacional, Rio de Janeiro. Ele éo grande organizador 
do projeto no Brasil, fez com que os seminários discutidos nos Estados Unidos fossem realizados também no Brasil. Lembro-me que conseguimos reunir em um seminário todos os integrantes norte-americanos Jean Lave, Joanna Bamberger, Jon Cristopher Crocker, Terence Turner - e brasileiros - Roberto D a Matta e Júlio César Melatti. Inventávamos sempre novas maneiras de nos encontrar, e incentivávamos esses alunos a ir a campo. Foi um período muito intensivo de pesquisa, tanto do lado americano como do brasileiro. E não era somente um período de pesquisa intensiva. Paralelamente, tive uma oportunidade que mudou a minha vida, a de colaborar com Roberto Cardoso de Oliveira na construção de um programa, que depois se tornou o Programa de Pós-G raduação em Antropologia Social do Rio de Janeiro. Hoje este é um dos lugares mais fortes da etnologia brasi-leira. O projeto Harvard Brasil Central e o Programa mantinham uma relação muito estreita desde 0 início e foi assim que a coisa progrediu.

\section{O Brasil indígena e suas vicissitudes}

O Programa de Pós-Graduação do Museu Nacional foi lançado em 1968, um momento muito crítico na história do Brasil, pois se tratava do auge da repressão. A vantagem disso para nós era o fato de os alunos da primeira turma serem brilhantes. Talvez muitos desses alunos não quisessem realmente ser antropólogos, mas apenas ter uma formação boa em ciências sociais, já que as outras vias de acesso estavam se fechando, visto que as ciências sociais eram consideradas subversivas pela ditadura. Em função desse programa, continuamos a pesquisa no Brasil Central. Ao mesmo tempo, iniciei, por causa de esquemas montados no Museu Nacional, uma pesquisa no Nordeste, mas que teve de ser, infelizmente, engavetada.

Naqueles anos, o Brasil estava sendo acusado de genocídio, dada a situação crescente de invasões de terras indígenas. Os índios que se 
opunham à chegada dos invasores eram cruelmente mortos com tiros. A expansão da fronteira no Brasil, ao contrário do que se deu na Argentina e no Chile, se intensificou no século XX. Moradores, mineradores, garimpeiros começaram a matar índios em uma época em que isso havia há muito deixado de ser politicamente correto.

\section{A Cultural Survival}

Ficamos muito preocupados com o destino dos povos do Brasil Central. E não apenas com eles. Atualmente, nossa pesquisa ampliou-se para incluir os problemas dos povos indígenas de toda parte e, naquela época, já estávamos bastante conscientes de nos confrontarmos com um problema mundial.Eu e minha esposa fomos conversar com os nossos colegas nos Estados Unidos, pensando que tínhamos alguma responsabilidade para com esses povos e que devíamos atuar em função disso. As respostas que recebemos eram muito decepcionantes. Nossos colegas concordavam que a situação dos povos indígenas era, de modo geral, crítica, no entanto, a maioria deles sentiu que não havia muita coisa que os antropólogos pudessem fazer. Felizmente, nem todo mundo pensava assim. Era um período em que muitas ONGs eram fundadas com uma intenção expressa de fornecer assistência aos povos indígenas. No Brasil, esse era o momento em que acadêmicos fundaram a Comissão Pró-Índio, e em que várias associações auto-denominadas Amigos dos Índios emergiram na sociedade civil. Assim, em 1972, partindo da iniciativa de Pia, fundamos a Cultural Survival, em Cambridge, Massachusets, nos Estados Unidos.

Nunca imaginamos que a Cultural Survival fosse salvar o mundo, mas fazíamos questão de mostrar que os mesmos problemas se encontram espalhados no mundo inteiro. Por meio da Cultural Survival, passamos a publicar e apurar dados a respeito desses problemas, e depois apresentar as análises para o Banco Mundial, para os governos 
de diversos países de modo a mostrar o que de fato está acontecendo e insistir que fossem tomadas providências para aliviar de alguma maneira a situação. Essa foi a proposta da Cultural Survival, e continua operando até os dias de hoje. A Cultural Survival, sediada em Cambridge, Massachusets, é hoje um centro de pesquisa, mas é, sobretudo, um centro de pesquisa para os próprios índios, pois são eles que devem se defender. As O NG s devem ajudá-los a fazer isso, mas não responder por eles.

\section{Entre duas Antropologias}

G ostaria de frisar o ponto de tensão entre o estudo etnológico de outras culturas, no meu caso de culturas indígenas americanas, e o estudo das circunstâncias sociopolíticas que as sociedades indígenas enfrentam, os chamados estudos de contato interétnico. Penso que ambas as tendências têm uma importância igual e devem ser fomentadas e desenvolvidas - para os índios, no entanto, as análises do indigenismo são certamente mais importantes...

Ao meu ver, o Brasil tem sorte, pois ambas as tendências se encontram igualmente distribuídas. Isso dáà Antropologia brasileira o destaque que ela merece, destaque que cresceu sobre as raízes que Roberto Cardoso de Oliveira, eu e outros brasileiros daquela geração cultivamos.

Sobre esse destaque muito bem merecido da Antropologia brasileira, há sempre o risco do desencadeamento de brigas desnecessárias e contraprodutivas. Mas essa tensão não é entre tendências opostas na Antropologia, pois não se trata de duas Antropologias irreconciliáveis, mas de uma simples tensão entre o que conseguimos realizar e o que é demais. Eu pretendia e ainda pretendo trabalhar nas duas áreas, penso que isso é possível e gostaria também de encorajar todos a pensar nessa possibilidade. Mas, se não for possível fazer as duas coisas, ao menos se deve tentar fazer uma bem feita, e deixar que outros façam a outra. É necessário, sobretudo, conversar com as pessoas que fazem a outra 
coisa. Eu sempre tive esse sentimento de ter dois empregos. Sei também que há pessoas que têm três, quatro ou mais, mas para mim, dois já é 0 bastante. E não só ter dois empregos, como seguir duas linhas de pesquisa, ter uma vida dividida. Mas, de todo modo, uma vida bem dividida.

São Paulo, 26 de outubro de 2001. 